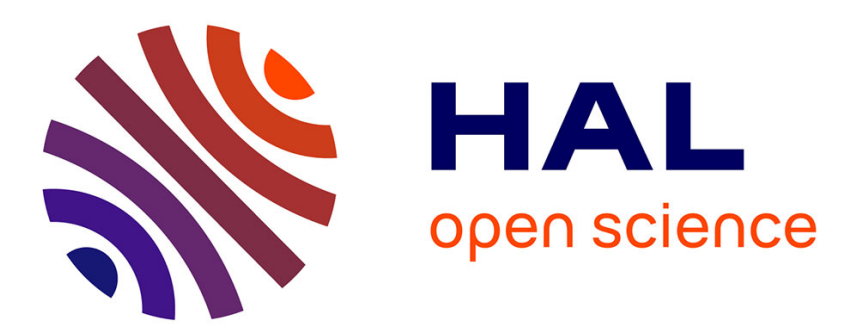

\title{
Development and investigation of tunable multicolour superbroadband solid state and dye lasers
}

\author{
A. Izmailov, G. Kund, A. Zhiglinskiy
}

\section{To cite this version:}

A. Izmailov, G. Kund, A. Zhiglinskiy. Development and investigation of tunable multicolour superbroadband solid state and dye lasers. Journal de Physique IV Proceedings, 1994, 04 (C4), pp.C4-613C4-613. 10.1051/jp4:19944163 . jpa-00252620

\section{HAL Id: jpa-00252620 https://hal.science/jpa-00252620}

Submitted on 1 Jan 1994

HAL is a multi-disciplinary open access archive for the deposit and dissemination of scientific research documents, whether they are published or not. The documents may come from teaching and research institutions in France or abroad, or from public or private research centers.
L'archive ouverte pluridisciplinaire HAL, est destinée au dépôt et à la diffusion de documents scientifiques de niveau recherche, publiés ou non, émanant des établissements d'enseignement et de recherche français ou étrangers, des laboratoires publics ou privés. 


\title{
Development and investigation of tunable multicolour superbroadband solid state and dye lasers
}

\author{
A.M. IZMAILOV, G.G. KUND and A.G. ZHIGLINSKIY
}

Physics Research Institute, Optics Dept., Peterburg University 198904, Ulianovskaia 1, St. Peterburg, Russia

\begin{abstract}
Lasers emitting simultaneousely several wavelengths can be widely used in scientific and applied investigations. For their successive application it is necessary to ensure broad spectral region where independent tuning of lasing lines is possible and to get high output power. In this paper intracavity losses are studied in multicolour dye lasers with violated modes competition /1/. It is shown that increase of the losses of radiation emitted by active medium off-ayis portions not only decrease the output energy, but also is the main reason limitting lasing spectrum width of such lasers. Novel optical scheemes of multicolour laser's cavities are suggested with decreased geometrical losses. Application of new resonators permits to widen the lasing spectrum of polychromatic dye lasers up to 2 times. Spectral and energetic characteristics are investigated of developed lasers with different dye solutions as an active medium. Superbraadband solid state lasers are constructed on the base of developed cavities. The width of the continuum radiated by such laser with an active medium made from a crystall of Lif with colour centers is operatable. It can be from $2 \mathrm{~nm}$ up to $60 \mathrm{~nm}$. An active element was pumped by Q-sweached ruby laser. Continuum of $15 \mathrm{~nm}$ wide was emitted also by the laser with lamp pumping ( Nd dapped glass GL5-22 was used as an active medium in this casel. Violation of modes competition in such lasers with homogeneously broadened amplification band of active medium permits to get the continuum up to 1 - 2 orders wider than that of conventional lasers with nondispersive cavities. Such a broad continuum can be useful for application of the developed lasers for absorbtion measurments. The abbility an advantages are discussed of multicolour lasers application in molecular spectroscopy, holography, biology, medicine, holographic interferometry, diagnostic of complex physical objects.
\end{abstract}

\section{Literature}

[1] Izmailov A.M., Zhiglinskiy A.G.// Vestnik LGU (Sov), V.4, N.25, p.71-73, 1992 . 